\title{
PENGARUH SISTEM EKSPLOITASI TERHADAP PRODUKSI KARET PADA KLON PB260
}

\section{EFFECT OF RUBBER PRODUCTION SYSTEM EXPLOITATION AGAINST THE PB260 CLONES}

\author{
${ }^{1}$ Yayuk Purwaningrum, ${ }^{2} \mathrm{JA}$. Napitupulu , ${ }^{3}$ Chairani Hanum, and ${ }^{4}$ THS Siregar \\ ${ }^{1}$ Fakultas Pertanian, Universitas Islam Sumatera Utara Medan \\ ${ }^{2}$ Program Studi Agroekoteknologi, Fakultas Pertanian, Universitas Sumatera Utara Medan 20155 \\ ${ }^{3}$ Program Studi Agroekoteknologi ,Fakultas Pertanian, Universitas Sumatera Utara Medan 20155 \\ ${ }^{4}$ Pusat Penelitian Karet Sungai Putih, Sumatera Utara \\ Coresponding author: yayuk_dadan@yahoo.com
}

\begin{abstract}
ABSTRAK
Penelitian ini bertujuan mempelajari fisiologi tanaman karet klon PB260 untuk mendapatkan system exploitasi yang tepat untuk meningkatkan produksi sesuai dengan karakter klon. Penelitian ini dilaksanakan di perkebunan karet klon PB260 umur 15 tahun kebun PTPN Nusantara III Sei Putih mulai April 2014 sampai April 2015. Penelitian ini menggunakan rancangan acak kelompok dengan sistem eksploitasi sebagai perlakuan dan masing-masing diulang sebanyak tiga kali. Sistem ekploitasi yang digunakan, yaitu sistem sadap (P) dengan empat taraf : $\mathrm{P}_{1}: \mathrm{S} / 2 \mathrm{~d} 3 \mathrm{BI}-1, \mathrm{P}_{2}: \mathrm{S} / 4$ d3 BI-1, $\mathrm{P}_{3}: \mathrm{S} / 2 \mathrm{U}$ d3 H0-1, $\mathrm{P}_{4}: \mathrm{S} / 4 \mathrm{U}$ d3 H0-1, dan jenis stimulan $(\mathrm{S})$ dengan empat taraf : $\mathrm{S}_{0}$ : Etepon $2.5 \%, \mathrm{~S}_{1}$ : Stimulan gas $3 \times$ sadap per aplikasi, $S_{2}$ : Stimulan gas $6 \mathrm{x}$ sadap per aplikasi, $\mathrm{S}_{3}$ : Stimulan gas $9 \mathrm{x}$ sadap per aplikasi. Hasil penelitian menunjukkan bahwa Sistem eksploitasi yang relative aman untuk klon PB260 adalah perlakuan sistem eksploitasi S/2 U d3 ETG/27d dan S/4U d3 ET /30d yang menghasilkan produksi $\left(\mathrm{g} \mathrm{p}^{-1} \mathrm{~s}^{-1}\right) 19.27 \mathrm{~g} \mathrm{p}^{-1} \mathrm{~s}^{-1}$ dan $18.90 \mathrm{~g} \mathrm{p}^{-1} \mathrm{~s}^{-1}$, dengan kadar tiol relative aman yaitu $0.4 \mathrm{mM}$.
\end{abstract}

Keywords: klon PB260, sistem exploitasi, sucrose, Pi, thiol.

\section{PENDAHULUAN}

Luas areal karet di Indonesia mencapai 3.4 juta hektar, dan 2.9 juta ha di antaranya lahan perkebunan rakyat (smallholders) atau sekitar 80 persen dari total perkebunan karet Indonesia, sementara luas areal Negara (goverement) yaitu 259.366 ha dan untuk perkebunan swasta (private) luas arealnya yaitu 269.315 ha (Dirjenbun, 2013).

Untuk produksi tanaman karet di Provinsi Sumatera Utara pada tahun 2012 yaitu 501.484 ton dengan luas lahan 470.202 ha, dan pada tahun 2013 naik menjadi 513.783 ton dengan luas lahan 475.724 ha, dari produksi perkebunan rakyat yaitu 250.800 ton dengan luas lahan 300.947 ha, perkebunan Negara yaitu 102.710 ton, luas lahan 71.945 ha dan perkebunan swasta 160.273 ton, luas lahan 101.723 ha (Dirjenbun, 2013).

Meskipun Indonesia memiliki wilayah cukup luas untuk tanaman karet, tetapi produktivitasnya masih berada di bawah Thailand, yaitu produktivitas tanaman karet rata-rata di Indonesia pada tahun 2007 baru mencapai $996 \mathrm{~kg}^{-1} \mathrm{ha}^{-1} \mathrm{thn}^{-}$ 1 masih lebih rendah dibandingkan Thailand, yaitu $1675 \mathrm{~kg}^{-1} \mathrm{ha}^{-1} \mathrm{thn}^{-1}$ (Bastari, 2008).

Terdapat sejumlah faktor yang menyebabkan Indonesia masih memerlukan usaha-usaha dalam peningkatan produksi. Salah satu faktor teknis yang perlu dipertimbangkan adalah rendahnya mutu penyadapan serta penerapan sistem eksploitasi tanaman di lapangan yang tidak sesuai dengan peraturan. Kenyataan seperti ini tidak 
hanya terjadi pada areal tanaman karet rakyat, tetapi juga di perkebunanperkebunan besar milik swasta dan pemerintah. Penyadapan yang salah menyebabkan pembentukan kulit pulihan akan terganggu, batang benjol-benjol, dan cadangan kulit habis. Batang yang tidak rata juga akan menyulitkan penyadapan selanjutnya. Karena itu, penerapan sistem sadap memerlukan pengawasan dan pengendalian, karena sistem sadap selain untuk mempertahankan umur ekonomi tanaman juga bermanfaat untuk perencanaan produksi pada periode mendatang (Siregar, 1995), serta tidak menyebabkan kerusakan pada tanaman (Sumarmaji, 2000).

Aplikasi stimulan memerlukan pengawasan yang lebih intensif, karena resiko dari aplikasi yang tidak benar adalah mengeringnya alur sadap. Penggunaan stimulan dalam jangka panjang untuk merangsang keluarnya lateks diduga menjadi salah satu penyebab penurunan produksi lateks di Perkebunan Karet. Pada kondisi yang paling merugikan, seluruh kulit cadangan mengalami kekeringan. Untuk itu dianjurkan agar selalu mengamati apa yang disebut dengan Brown Bast. Gejala yang dapat dilihat adalah berubahnya sebagian warna alur sadap menjadi cokelat kehitaman dan tidak mengalirkan lateks lagi (Siregar, 1995). Dalam kurun waktu yang relatif singkat, hampir semua perkebunan besar menggunakan stimulan dalam mengeksploitasi tanaman karetnya. Stimulan yang banyak digunakan pada perkebunan besar adalah stimulan Etephon. Faktor pendorong yang membuat cepat meluasnya penggunaan stimulan etephon ini adalah karena pengaruhnya yang sangat efektif dalam meningkatkan produksi lateks (Dompu, 2001) dan pohon karet memiliki umur produksi hingga 30 tahun (Indraty, 2002).

Klon unggul (Quick Starter) QS Indonesia antara lain PB 235, 260, 280, 340. Saat ini, perkebunan Negara maupun swasta lebih memilih mengadopsi klon $Q S$ dengan pertimbangan puncak produksi dapat dicapai lebih cepat dan produktivitas per tahun tinggi (Siregar, 2008). Setiap klon memiliki karakter fisiologi yang berbeda sehingga diperlukan system sadap (penggalian produksi) yang berbeda pula. Penyadapan yang tidak berdasarkan tipologi klonal akan menyebabkan terjadinya penyadapan yang berlebihan (Over exploitation) atau kekurangan intensitas eksploitasi (Under exploitation). Kesalahan dalam penyadapan akan membawa akibat yang sangat merugikan baik bagi pohon itu sendiri maupun bagi produksinya. Hal ini akan menyebabkan pemborosan pemakaian dan kerusakan kulit yang akan berdampak pada pemendekan umur ekonomis tanaman, penurunan produksi sehingga mengakibatkan kerugian perusahaan, oleh karena itu perlu dikaji sistem eksploitasi sesuai dengan tipelogi klon sehingga penelitian ini bertujuan untuk mengetahui system exploitasi yang tepat dalam meningkatkan produksi sesuai dengan karakter klon.

\section{BAHAN DAN METODE}

Penelitian dilaksanakan di dua lokasi yaitu Kebun Percobaan Balai Penelitian Sungei Putih, Pusat Penelitian Karet Sumatera Utara dan perkebunan karet PT. Perkebunan Nusantara III (Persero). kebun Sungei Putih, Kabupaten Deli Serdang Sumatera Utara, dari 5April 2014 sampai 28 April 2015.

Bahan tanaman yang digunakan di lapangan adalah tanaman karet klon PB260 berumur 15 tahun (tahun tanam 1999), dengan jarak tanam $2.5 \times 5 \mathrm{~m}$ (populasi 800 pohon ha ${ }^{-1}$ ). Pengamatan penelitian meliputi produksi tanaman di lapangan pada perkebunan karet PT. Perkebunan Nusantara III (Persero), kebun Sungei Putih, serta analisis fisiologi lateks yang dilakukan di Laboratorium Balai Penelitian Sungai Putih.

Percobaan lapangan menggunakan rancangan acak kelompok faktorial tiga ulangan dengan sistem eksploitasi sebagai 
perlakuan. Sistem eksploitasi yang diberikan terdiri dari dua perlakuan, yaitu sistem sadap $(\mathrm{P})$ dan jenis stimulan $(\mathrm{S})$, masing-masing terdiri dari empat taraf. Sistem sadap $(\mathrm{P})$ yang diberikan yaitu: $\mathrm{P}_{1}=$ $\mathrm{S} / 2 \mathrm{~d} 3 \mathrm{BI}-1, \mathrm{P}_{2}=\mathrm{S} / 4$ d3 BI-1, $\mathrm{P}_{3}=\mathrm{S} / 2 \mathrm{U}$ d3 H0-1, $\mathrm{P}_{4}=\mathrm{S} / 4 \mathrm{U}$ d3 H0-1, dan jenis stimulan $(\mathrm{S})$ yang diberikan yaitu: $\mathrm{S}_{0}=$ Etepon $2.5 \%, \mathrm{~S}_{1}=$ Stimulan gas $3 \mathrm{x}$ sadap per aplikasi, $S_{2}=$ Stimulan gas $6 \times$ sadap per aplikasi, $S_{3}=$ Stimulan gas $9 \times$ sadap per aplikasi. Variabel yang diamati di lapangan adalah produksi lateks, sukrosa, P-inorganik (Pi) dan tiol yang akan dianalisis di laboratorium.

\section{Analysis Physiology}

Kadar sukrosa, fosfat anorganik dan tiol diukur dengan cara diagnosis lateks menggunakan contoh berupa serum lateks TCA (asam trikloro-asetat). Serum lateks TCA dibuat dengan cara $1 \mathrm{ml}$ lateks dan $9 \mathrm{ml}$ TCA dicampur secara merata dalam botol film sampai terbentuk gumpalan karet dan serum TCA. Kemudian, gumpalan karet di dalam larutan tersebut diambil dan serum TCA disaring menggunakan kertas saring, kemudian dianalisis.

a. Analisis kadar sukrosa (mM) dapat diukur dengan metode anthrone: serum TCA diambil sebanyak 150 $\mu \mathrm{L},($ ditambahkan larutan TCA $2.5 \%$ sampai volume total $150 \mu \mathrm{L}$ ) dan ditambah pereaksi anthrone 3 $\mathrm{ml}$, kemudian diaduk supaya tercampur rata menggunakan vortex. Setelah itu, dipanaskan dengan merendam di dalam air mendidih selama 15 menit dan didinginkan kembali dengan merendam dalam air $\rightarrow$ Absorbansi. Absorbansi diukur pada $\lambda \quad 627 \quad \mathrm{~nm}$ dengan spektrofotometer Beckman DU 650 [12].

Consentrasi Sucrose * 33,3

(1)

b. Analisi kadar fosfat anorganik (Pi) diukur menggunakan metode [13], berdasarkan prinsip pengikatan oleh amonium molibdat yang tereduksi oleh $\mathrm{FeSO}_{4}$ dalam reaksi asam sehingga membentuk warna biru, kemudian absorbannya diukur pada $\lambda \quad 627 \quad \mathrm{~nm}$ dengan spektrofotometer Beckman DU 650.

Consentrasi $\mathrm{Pi} * 50$

c. Analisis kadar tiol (R-SH) sampel diambil $1.5 \mathrm{ml}$ (ditambah larutanTCA $2.5 \%$ sampai volume total $1.5 \mathrm{ml}$ ), ditambah DTNB 10 $\mathrm{mM} 75 \mu \mathrm{L}$ dan ditambah larutan bufer Tris $0.5 \mathrm{M}$ sebanyak $1.5 \mathrm{ml}$, kemudian diaduk supaya tercampur rata menggunakan vortex. Kemudian, larutan didiamkan pada suhu kamar selama 30 menit $\rightarrow$ Absorbansi. Absorbansi dibaca pada $\lambda 421 \mathrm{~nm}$ menggunakan spektrofotometer Beckman DU 650 atau diukur dari serum TCA berdasarkan prinsip reaksinya menggunakan asam dithiobisnitrobenzoat (DTNB) untuk membentuk TNB berwarna kuning yang terabsorbsi pada $\lambda 421 \mathrm{~nm}$ menggunakan spektrofotometer Beckman DU 650 [14].

Consentrasi tiol * 10/1000

d. Produksi Karet $\left(\mathrm{g} \mathrm{p}^{-1} \mathbf{s}^{-1}\right)$

Untuk mendapatkan produksi kering, data produksi dari lapangan dikali dengan KKK yang diperoleh dari analisis di kebun. Persamaan pengukuran karet kering (KKK) adalah sebagai berikut : $\mathrm{BK}=\mathrm{BB} \mathrm{x}$ KKK.

Dimana BK : Berat kering (g); BB : Berat Basah (g); KKK : Kadar Karet Kering (\%)

Untuk mengukur produksi kering $\left(\begin{array}{lll}g & \mathrm{p}^{-1} & \mathrm{~s}^{-1}\end{array}\right)$, BK dibagi jumlah tanaman yang disadap dan banyaknya hari sadap dengan persamaan sebagai berikut : 
Produksi Kering $\left(\mathrm{g} \mathrm{p}^{-1} \mathrm{~s}^{-1}\right)=\mathrm{BK} /$ $\left(\sum \mathrm{p} / \sum \mathrm{s}\right)$

Dimana $\sum \mathrm{p}$ : jumlah pohon; $\sum \mathrm{s}$ : jumlah hari sadap $\sum \mathrm{s}$ : jumlah hari sadap

\section{Statistical Analysis}

In experimental design, data were analyzed using the Statistical Analysis System (SAS) Software 9.1, SAS Institute Ltd., USA. Mean comparisons were made using the Duncan's multiple range tests at the 0.05 level of probability based on the analysis of variance.

\section{HASIL DAN PEMBAHASAN}

\section{Fisiologi Klon PB260}

Sistem eksploitasi dapat memberikan cekaman fisiologis terhadap tanaman karet, sehingga perlu dilakukan pengamatan parameter fisiologis melalui diagnosis lateks yang bertujuan untuk mengetahui pengaruh sistem eksploitasi terhadap kondisi kesehatan tanaman (Sumarmadji et al., 2006)

Hasil penelitian pada Tabel 1 menunjukkan bahwa sistem eksploitasi berpengaruh nyata terhadap produksi $\left(\mathrm{g} \mathrm{p}^{-}\right.$ $\left.{ }^{1} \mathrm{~s}^{-1}\right)$, produksi $\left(\mathrm{g} \mathrm{p}^{-1} \mathrm{~s}^{-1}\right)$ tertinggi diperoleh pada perlakuan S/2 U d3 ETG /27d dan produksi $\left(\mathrm{g} \mathrm{p}^{-1} \mathrm{~s}^{-1}\right)$ terendah pada perlakuan $\mathrm{S} / 4$ d3 ET $/ 30$ hari sekali. Tinggi produksi $\left(\mathrm{g} \mathrm{p}^{-1} \mathrm{~s}^{-1}\right)$ pada perlakuan $\mathrm{S} / 2 \mathrm{U} \mathrm{d} 3$ ETG /27hari sekali diduga disebabkan oleh irisan sadap yang panjang ke arah atas, aplikasi stimulant gas 27 hari sekali. Sadapan arah ke atas memberikan hasil yang lebih baik karena pada SKA jarak antara bidang sadap dengan tajuk tanaman lebih dekat, pemberian stimulant 27 hari sekali memberikan waktu yang cukup bagi tanaman untuk melakukan sintesis sepenuhnya lateks untuk dipanen sehingga kandungan sukrosa meningkat, aktifitas metabolisme cukup kandungan $\mathrm{Pi}$ $(27 \mathrm{mM})$. Hal ini sependapat dengan hasil penelitian Lukman (1996) yang menyatakan kelebihan sistem sadap arah atas (SKA) dapat meningkatkan produktivitas tanaman, hal ini karena sadapan tepat memotong pembuluh lateks dengan kemiringan $90^{\circ}$ sehingga lateks mengalir keluar lancer.

Produksi $\left(\mathrm{g} \mathrm{p}^{-1} \mathrm{~s}^{-1}\right)$ yang rendah pada perlakuan S/4 d3 ET /30 hari sekali diduga disebabkan oleh irisan arah ke bawah (SKB) dan pemberian etepon 30 hari sekali, hal ini diduga sadapan arah bawah terputusnya hubungan antara bidang sadap dengan tajuk, sehingga kurang lancar proses regenerasi lateks karena aliran fotosintat yang merupakan bahan dasar pembuatan lateks terhambat, kemudian di dukung oleh rendahnya frekuensi aplikasi stimulant mengakibatkan produksi $\left(\mathrm{g} \mathrm{p}^{-1} \mathrm{~s}^{-1}\right)$ yang rendah. Aplikasi stimulant 30 hari sekali diduga belum dapat mengaktifkan pompa proton $\mathrm{H}^{+}$untuk meningkatkan laju aliran lateks. Hal ini sejalan dengan hasil penelitian Doungmasik dan Sdoodee (2012) klon RRIM, yang menyatakan sistem sadap ke arah bawah (SKB), aliran fotosintat (fotosintat dihasilkan dari daun) kepembuluh - pembuluh lateks terganggu oleh irisan sadap.

Sukrosa merupakan variabel yang penting. Kaitannya dengan bahan utama dalam pembentukan lateks. Dari Tabel 1 dapat dilihat hasil analisis kadar sucrose lateks tanaman karet klon PB260 menunjukkan bahwa kadar sukrosa klon PB260 dipengaruhi oleh sistem eksploitasi. Sistem eksploitasi yang menghasilkan kadar sukrosa tinggi adalah sistem sadap dengan perlakuan S/4 d3 ETG / 9 hari sekali diduga disebabkan oleh irisan sadap yang pendek dan aplikasi stimulant gas 9 hari sekali. Semakin pendek irisan akan meningkatkan laju tekanan aliran lateks dan gangguan terhadap anggkutan assimilate semakn kecil (Suhermanto dan Sumarmadji, 2005). Hasil ini sejalan dengan penelitian sejalan dengan hasil penelitian Herlinawati dan Kuswanhadi penyadapan irisan pendek yang dikombinasikan dengan penggunaan stimulan gas etilen dapat meningkatkan produktivitas sekitar 66,1- 76,2\%. Serta pemberian stimulant 9 hari sekali mampu 
memobilisasi karbohidrat sehingga kandungan sukrosa meningkat, aktifitas metabolism cukup pada kandungan $\mathrm{Pi}$ (21.50 mM.

Tabel 1. Diagnosis Lateks klon PB260 dengan berbagai sistem eksploitasi

\begin{tabular}{|c|c|c|c|c|c|c|}
\hline \multirow{2}{*}{\multicolumn{2}{|c|}{ Sistem Eksploitasi }} & \multicolumn{5}{|c|}{ Analisis Fisiologi } \\
\hline & & Produksi $\left(\mathrm{g} \mathrm{p}^{-1} \mathrm{~s}^{-1}\right)$ & \multicolumn{2}{|c|}{ Sucrose } & $\begin{array}{l}\mathrm{Pi} \\
\ldots \mathrm{mM}\end{array}$ & $\begin{array}{l}\text { R-SH } \\
\ldots \ldots \ldots\end{array}$ \\
\hline $\mathrm{S} / 2 \mathrm{~d} 3$ & ET $/ 15 d$ & $9.40 \quad \mathrm{~g}$ & 4.83 & $\mathrm{e}$ & $19.25 \mathrm{gh}$ & $0.35 \mathrm{i}$ \\
\hline $\mathrm{S} / 2 \mathrm{~d} 3$ & ETG / 9d & $10.31 \mathrm{f}$ & 4.33 & $\mathrm{e}$ & 22.75 ef & $0.46 \mathrm{~cd}$ \\
\hline $\mathrm{S} / 2 \mathrm{~d} 3$ & ETG /18d & 8.75 hi & 9.66 & d & $12.50 \mathrm{i}$ & $0.64 \mathrm{a}$ \\
\hline $\mathrm{S} / 2 \mathrm{~d} 3$ & ETG /27d & $9.04 \mathrm{gh}$ & 3.95 & $\mathrm{e}$ & $13.25 \mathrm{i}$ & $0.42 \mathrm{~g}$ \\
\hline $\mathrm{S} / 4 \mathrm{~d} 3$ & $\mathrm{ET} / 15 \mathrm{~d}$ & $8.37 \quad \mathrm{i}$ & 11.32 & $\mathrm{~cd}$ & $28.50 \mathrm{bc}$ & $0.36 \mathrm{i}$ \\
\hline $\mathrm{S} / 4 \mathrm{~d} 3$ & ETG / 9d & $7.30 \mathrm{j}$ & 24.48 & $\mathrm{a}$ & $21.50 \mathrm{fgh}$ & $0.39 \mathrm{~h}$ \\
\hline $\mathrm{S} / 4 \mathrm{~d} 3$ & ETG /18d & $7.37 \mathrm{j}$ & 4.83 & $\mathrm{e}$ & $18.25 \mathrm{~h}$ & $0.47 \mathrm{c}$ \\
\hline $\mathrm{S} / 4 \mathrm{~d} 3$ & ETG /27d & $6.85 \mathrm{j}$ & 17.99 & $\mathrm{~b}$ & $22.42 \mathrm{efg}$ & $0.44 \mathrm{efg}$ \\
\hline $\mathrm{S} / 2 \mathrm{Ud} 3$ & $\mathrm{ET} / 15 \mathrm{~d}$ & $16.29 \mathrm{c}$ & 13.33 & $\mathrm{c}$ & $25.00 \mathrm{de}$ & 0.44 ef \\
\hline $\mathrm{S} / 2 \mathrm{Ud} 3$ & ETG / 9d & $17.09 \mathrm{~b}$ & 4.50 & $\mathrm{e}$ & $21.25 \mathrm{fgh}$ & $0.47 \mathrm{c}$ \\
\hline $\mathrm{S} / 2 \mathrm{Ud} 3$ & ETG /18d & $15.63 \mathrm{~d}$ & 5.00 & $\mathrm{e}$ & $21.00 \mathrm{fgh}$ & $0.51 \mathrm{~b}$ \\
\hline $\mathrm{S} / 2 \mathrm{Ud} 3$ & ETG /27d & $19.27 \mathrm{a}$ & 3.50 & $\mathrm{e}$ & $27.00 \mathrm{~cd}$ & $0.47 \mathrm{c}$ \\
\hline $\mathrm{S} / 4 \mathrm{U} \mathrm{d} 3$ & ET $/ 30 d$ & $18.90 \mathrm{a}$ & 5.49 & e & 25.50 cde & $0.43 \mathrm{fg}$ \\
\hline $\mathrm{S} / 4 \mathrm{U}$ d3 & ETG / 9d & $15.79 \mathrm{~cd}$ & 6.33 & $\mathrm{e}$ & $37.75 \mathrm{a}$ & $0.40 \mathrm{~h}$ \\
\hline $\mathrm{S} / 4 \mathrm{U}$ d3 & ETG /18d & $10.35 \mathrm{f}$ & 4.44 & $\mathrm{e}$ & $37.50 \mathrm{a}$ & $0.52 \mathrm{~b}$ \\
\hline $\mathrm{S} / 4 \mathrm{U} \mathrm{d} 3$ & ETG /27d & $12.19 \mathrm{e}$ & 4.67 & e & $31.00 \mathrm{~b}$ & $0.45 \mathrm{de}$ \\
\hline
\end{tabular}

Note : Data in the same column followed by the common letters are not significantly different at the $\mathrm{P}=0.05$ level according to the Duncan's Multiple Range Test.

Kadar Phospat inorganic (Pi) dalam lateks menggambarkan kemampuan tanaman mengubah bahan baku (sukrosa) menjadi partikel karet. Kadar Pi dalam lateks menunjukkan aktifitas metabolisme dalam pembuluh lateks, kadar $\mathrm{Pi}$ yang tinggi menunjukkan aktivitas metabolism yang tinggi dan sebaliknya Gohet et al., 2008 Kadar (Pi) lateks klon PB260 dipengaruhi oleh system eksploitasi. Dari Tabel 1 dapat dilihat sistem eksploitasi yang menghasilkan kadar Pi tinggi adalah sistem eksploitasi dengan perlakuan sistem sadap S/4U d3 ETG / 9d, tidak berbeda nyata dengan perlakuan $\mathrm{S} / 4 \mathrm{U}$ d3 ETG /18d. Kandungan Pi mengalami peningkatan metabolisme sel lateks menjadi aktif dengan penggunaan sistem sadap irisan pendek dan pemberian stimulan 9 hari sekali dan 18 hari sekali dapat dilihat kandungan sukrosa mengalami penurunan ( $4.44 \mathrm{mM})$. Akibat peningkatan $\mathrm{Pi}$ aktivitas metabolisme meningkat kandungan sukrosa menurun Gohet et al., 2008.

Kadar thiol merupakan indikasi penting pada tanaman karet berhubungan dengan kejadian KAS. Semakin tinggi intensitas eksploitasi, maka akan semakin tinggi kadar tiol .Thiol berfungsi sebagai antioksidan, sehingga stress oksidatif 
sebagai akibat aktifnya metabolism dalam sel dapat ditekan Jaco, et al., 1998. Dari Tabel 1 dapat dilihat sistem eksploitasi mempengaruhi kadar thiol lateks klon PB260 dengan kadar thiol tinggi yaitu pada sistem eksploitasi dengan perlakuan system sadap S/2 d3 ETG /18d. Hasil penelitian ini menunjukkan bahwa sistem eksploitasi yang diberikan pada klon PB260 masih dalam batas aman untuk kesehatan tanaman, karena kadar thiol yang dihasilkan umumnya rendah sampai sedang $0.3-0.5 \mathrm{mM}$. Menurut hasil penelitian Junaidi et al., 2010 klon PB260 umumnya kadar thiol sedang $0.3-0.6$ $\mathrm{mM}$. Sistem eksplotasi pada perlakuan system sadap S/2 d3 ETG/18d. Kadar $\mathrm{R}-\mathrm{SH}$ yang tinggi menunjukkan terlalu intensifnya eksploitasi sehingga perlu dikurangi dengan menurunkan intensitas sadap maupun stimulasi (Gohet, 1996:Gohet 2008).

Hubungan Produksi $\left(\mathrm{g} \mathrm{p}^{-1} \mathrm{~s}^{-1}\right)$ dengan Pi (mM) dan Sukrosa (mM)

Peningkatan produksi lateks karena perlakuan eksploitasi berhubungan dengan keseimbangan karakter fisiologi yang sangat kompleks dan spesifik dalam menghasilkan lateks (Sumarmadji et al., 2008) Penurunan kondisi fisiologis tanaman dapat diketahui dengan mengamati produksi lateks dan diagnosis lateks. Apabila terjadi cekaman eksploitasi yang berat, maka produksi lateks akan menurun secara drastis. Hasil analisis regresi-korelasi antara produksi $\left(\mathrm{g} \mathrm{p}^{-1} \mathrm{~s}^{-1}\right)$ dengan kadar Posfat inorganic (Pi) (mM) disajikan dalam bentuk Gambar 1 A. Posfat inorganic $(\mathrm{Pi})$ adalah indicator bagi aktifitas metabolic, dalam hal ini mengambarkan kemampuan tanaman mengubah bahan baku (sukrosa) menjadi partikel karet. Kadar $\mathrm{Pi}$ yang tinggi menunjukkan aktivitas metabolisme yang tinggi dan sebaliknya Lacote, et al., 2010. Pada umumnya produksi tanaman makin tinggi dengan semakin tingginya kadar Pi dalam lateks. Hasil analisis regresikorelasi antara produksi $\left(\mathrm{g} \mathrm{p}^{-1} \mathrm{~s}^{-1}\right)$ dengan kadar Pi (mM) disajikan dalam bentuk Gambar 1 A, menunjukkan bahwa hubungan antara produksi $\left(\mathrm{g}^{-1} \mathrm{~s}^{-1}\right)$ dengan Pi $(\mathrm{mM})$ relative rendah kecil $\left(\mathrm{R}^{2}\right.$ $=0.17$ ), terlihat juga bahwa hubungan antara kadar produksi $\left(\mathrm{g} \mathrm{p}^{-1} \mathrm{~s}^{-1}\right)$ dengan kadar Pi (mM) adalah berbentuk kwadratik, yang berarti semakin meningkat kadar $\mathrm{Pi}$ (mM) sampai batas optimum maka produksi $\left(\mathrm{g} \mathrm{p}^{-1} \mathrm{~s}^{-1}\right)$ juga meningkat.

Hasil analisis regresi-korelasi antara produksi $\left(\mathrm{g} \mathrm{p}^{-1} \mathrm{~s}^{-1}\right)$ dengan kadar sukrosa (mM) disajikan dalam bentuk Gambar 1 B. Sukrosa merupakan bahan dasar terbentuknya lateks. Kaitannya dengan bahan utama dalam pembentukan lateks. Kadar sukrosa yang tinggi menunjukkan produksi $\left(\mathrm{g} \mathrm{p}^{-1} \mathrm{~s}^{-1}\right)$ yang tinggi dan sebaliknya Lacote, et al., 2010 Pada umumnya produksi tanaman makin tinggi dengan semakin tingginya kadar sukrosa dalam lateks. Hasil analisis regresi-korelasi antara produksi $\left(\mathrm{g} \mathrm{p}^{-1} \mathrm{~s}^{-1}\right)$ dengan kadar sukrosa $(\mathrm{mM})$ disajikan dalam bentuk Gambar $1 \mathrm{~B}$, menunjukkan bahwa hubungan antara produksi $\left(\mathrm{g} \mathrm{p}^{-1} \mathrm{~s}^{-1}\right)$ dengan sukrosa $(\mathrm{mM})$ relative rendah kecil $\left(\mathrm{R}^{2}=0.31\right)$, terlihat juga bahwa hubungan antara kadar produksi $\left(\mathrm{g} \mathrm{p}^{-1} \mathrm{~s}^{-1}\right)$ dengan kadar sukrosa (mM) adalah berbentuk kwadratik terbalik. 

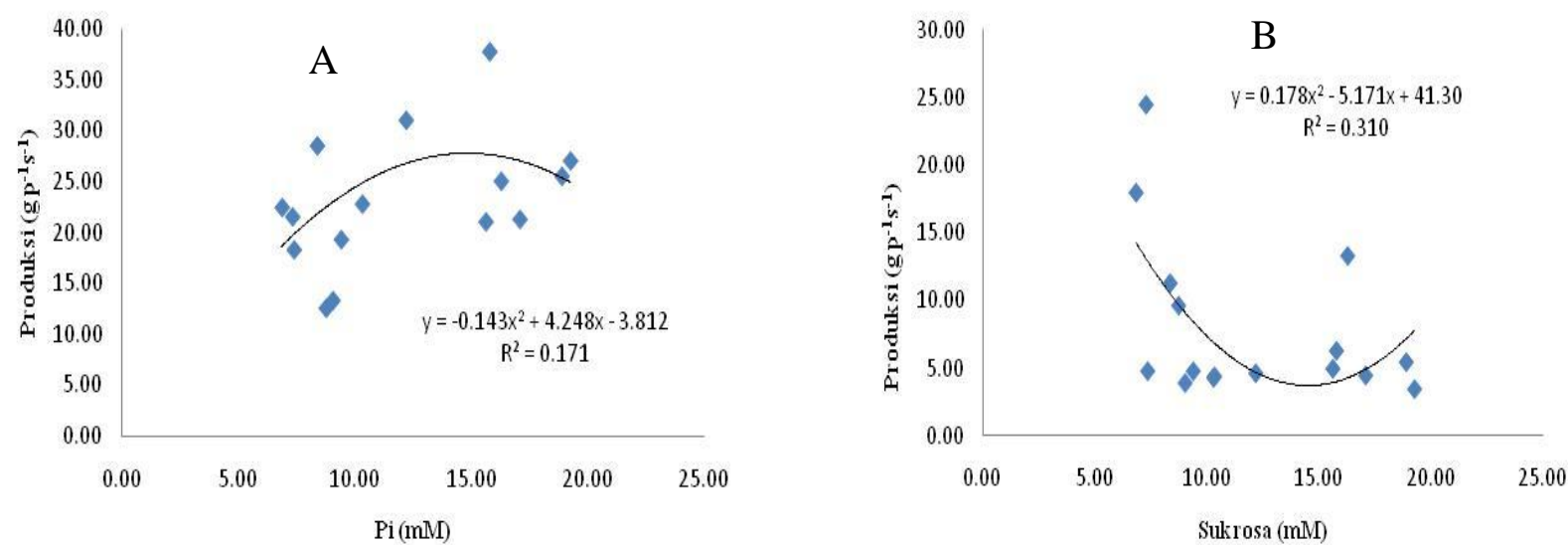

Figure 1. Hubungan Produksi $\left(\mathrm{g} \mathrm{p}^{-1} \mathrm{~s}^{-1}\right)$ dengan Pi (mM) (A) dan Sukrosa (mM) (B)

Secara umum dapat dikatakan bahwa produksi $\left(\mathrm{g} \mathrm{p}^{-1} \mathrm{~s}^{-1}\right)$, cenderung naik bila intensitas aplikasi stimulan direndahkan $\mathrm{S}_{0}$ (ET 2.5\% 30 hari sekali) dan $\mathrm{S}_{2}$ (ETG 18 hari sekali), tetapi kemudian menurun bila intensitas aplikasi stimulan ditinggikan $\mathrm{S}_{1}$ (9 hari sekali ETG ). Hal ini dapat dilihat pada Tabel 1 . Penurunan intensitas eksploitasi pada aplikasi stimulan $\mathrm{S}_{0}$ (ET 2.5\%) dan $\mathrm{S}_{2}$ (ETG 18 hari sekali) meningkatkan produksi $\left(\mathrm{g} \mathrm{p} \mathrm{p}^{-1} \mathrm{~s}^{-1}\right)$, berarti aplikasi stimulant tersebut tidak terlalu berat, sehingga memberikan waktu yang cukup bagi tanaman untuk melakukan sintesis sepenuhnya lateks untuk dipanen, hasil penelitian Do, A.N. (1998) menyimpulkan bahwa sistem eksploitasi dengan intensitas rendah menghasilkan lateks dengan produksi $\left(\mathrm{g} \mathrm{p}^{-1} \mathrm{~s}^{-1}\right)$, tinggi sebagai konsekuensi dari tersedianya waktu untuk meregenerasi lateks didalam pembuluh lateks.

\section{SIMPULAN}

Hasil penelitian menunjukkan bahwa sistem eksploitasi yang digunakan umumnya baik, dapat dilihat dari kadar thiol masih batas aman $0.3-0.6 \mathrm{mM}$. Sistem eksploitasi relative aman untuk klon PB260 adalah perlakuan dengan sistem sadap S/2 U d3 ETG /27d dan $\mathrm{S} / 4 \mathrm{U}$ d3 ET /30d yang menghasilkan produksi $\left(\mathrm{g} \mathrm{p}^{-1} \mathrm{~s}^{-1}\right) 19.27 \mathrm{~g} \mathrm{p}^{-1} \mathrm{~s}^{-1}$ dan 18.90 g $\mathrm{p}^{-1} \mathrm{~s}^{-1}$ dengan kadar tiol relative aman yaitu $0.4 \mathrm{mM}$.

\section{UCAPAN TERIMAKASIH}

Penulis mengucapkan terimakasih yang sebesar-besarnya kepada Dinas Pendidikan/Hibah Disertasi yang telah mendanai penelitian ini, kepada Pusat Penelitian Karet Sungai Putih, dan PT. Perkebunan Nusantara III (Persero) Sumatera Utara Indonesia, serta para Dosen Pembimbing yang telah banyak memberikan masukkan untuk berjalannya penelitian dan semua pihak yang telah membantu dalam penelitian ini.

\section{DAFTAR PUSTAKA}

Bastari, D. H. 2008. The Production of Indonesian Natural Rubber and Its Outlook. Slide presentation of Gapkindo in The Fifth Shanghai Derivetives Market Forum. 24 p.

Dirjenbun. 2013. Statistik Perkebunan Indonesia Tahun 2011 2013.Jakarta.

Dische. Z.M."Carbohydrate Chem". Acad. Press. 1962.vol.1: pp. 488.

Dompu, M. I. 2001. Sistem Penyadapan Karet (Hevea brasilliensis Muell Arg.) Pada Perkebunan Sei Kukui PT Pinago Utama Sumatera Selatan. Skripsi. Program Sarjana, Institut Pertanian Bogor. Bogor. 83 hal. 
Gohet, E.,P. Chantuma, R. Lacote, S. Obouayeba, K.Dian, A.C.Demange, D. Kurnia, and J.M. Eschbach. 2003. Physiology modeling of yield potential and clonal response to ethepon stimulation. IRRDB Workshop on Exploitation Technology.Kottayam. India.

H. H.Taussky, E. Shorr. "A micro colorimetric methods for the determination of inorganic". 1953.

Indraty, I. S. 2002. Perubahan produktivitas dan jaringan panel sadap tanaman karet akibat penggunaan stimulan jangka panjang. Jurnal Penelitian Karet. 20 (1-3): 30-42.

Junaidi, U. Sumarmadji, dan Atmaningsih. 2010. Pengujian Sistem Eksploitasi EXPEX-315 pada klon PB 260. $J$. Penelitian Karet, 28 (2),41-55.

K.T. Do, A.N. Ngia.'Evolution of latex physiological parameter of Heve brasiliensis tree over consucutive tapping year" . Colloque 98: 1825.1998.

Lacote, R.O. Gabla, S.Obouyeba, J.M. Eschbach, F.Rivano,K.Dian and E.Gohet.2010. Long term effect of ethylene stimulation on the yeild of rubber trees is linked to latex cell biochemistry. Field Crops Reaserch. 115, 94-97.

Lukman. 1996. Pengggunaan Sadapan Ke arah Atas (SKA) dengan Intensitas Eksploitasi Rendah untuk meningkatkan Produksi dan Umur Ekonomi Tanaman Karet.Jurnal penelitian Karet.13(2):85-98.

McMullen. A.I." Thiols of low molecular weight in Hevea brasiliensis latex". Biochem. Biophys. 1960. Acta vol.41: pp. 152-154.
SAS Institute Inc. SAS/STAT ${ }^{T M}$ Guide for Personal Computers, Version 6ed. SAS Institute Inc., Cary, NC. 2004.

Siregar, T.H.S., Junaidi, U., Sumarmadji, Siagian, N. dan Karyudi. 2008. Perkembangan Penerapan Rekomendasi Sistem Eksploitasi Tanaman Karet di Perusahaan Besar Negara. Prosiding Lokakarya Nasional Agribisnis Karet 2008 Yogyakarta, 20-21 Agustus 2008 . 220 hal.

Siregar, T.HS. 1995. Teknik Penyadapan Karet. Kanisius. Yogyakarta. 50p.

Sumarmadji, Karyudi, dan Siregar., T.H.S. 2006. Rekomendasi Sistem Eksploitasi pada Klon Quick Starter dan Slow Starter serta Penggunaan Irisan Ganda untuk Meningkatkan Produktivitas Tanaman Karet. Prosiding Lokakarya Nasional Budi Daya Tanaman Karet, Medan 4-6 September 2006. Balai Penelitian Sungei Putih, Pusat Penelitian Karet, Medan. hlm. 169-188.

Sumarmadji, Atminingsih dan Karyudi. 2008. Konsep Penyadapan Klon Slow Stater dengan Stimulan Gas Etilen dan Irisan Pendek ke Arah Atas sejak Awal Sadap. Prosiding Lokakarya Agribisnis Karet 2008, Yogyakarta 20 - 21 Agustus 2008. Balai Penelitian Sungei Putih, Pusat Penelitian Karet, Medan. hlm. 1375 - 386. 